\title{
IMPLEMENTASI GENETIC FUZZY SYSTEM UNTUK MENGIDENTIFIKASI HASIL CURIAN KENDARAAN BERMOTOR DI POLDA LAMPUNG
}

\author{
Arie Setya Putra ${ }^{1}$, Ochi Marshella Febriani ${ }^{2}$, Bobby Bachry ${ }^{3}$ \\ ${ }^{1}$ Program Studi Sistem Informasi Universitas MITRA Lampung \\ 2 Program Studi Sistem Informasi Institut Informatika dan Bisnis Darmajaya, \\ ${ }^{3}$ Program Studi Sistem Informasi Institut Informatika dan Bisnis Darmajaya \\ Iariesetyaputra@umitra.ac.id \\ ${ }^{2}$ ochimarshella@gmail.com \\ 3bobbachry@gmail.com
}

\begin{abstract}
The development of this technology is very fast, one of the media that utilizes technology such as application DPB Ranmor 2.0 in Polda Lampung That's in Play Store. In This Case will be solved by genetic Fuzzy System, most notably the development of the Genetic Fuzzy tree Methodology, have allowed fuzzy logic based Artificial Intellegence to be developed Application that can be applied to incredibly complex problem. The Ability of Information Retrieval to have extreme performance and computational efficiency as well as to be robust to uncertainties and randomness. The concept will be adopted for case Criminal in Lampung. Thief and Criminal in lampung its more completed, thiefs will sell his results of crime anywhere DPB Ranmor its one of Application will be pushed in results criminal ( ranmor). This methodology is an ideal solution to a very wide array of problems.
\end{abstract}

Keywords : Genetic Fuzzy Systems; Artificial Intellegence; Informasi retrieval; Aplikasi

\begin{abstract}
Abstrak
Perkembangan teknologi saat ini sangat cepat, banyaknya media dan alat pendukung yang disediakan dalam mengembangkan sistem menjadi salah satu alasan dapat dikembangkan nya sebuah aplikasi sistem. salah satu media yang memanfaatkan teknologi seperti aplikasi DPB Ranmor 2.0 di Polda Lampung yang telah tersedia di Play Store. Polda lampung merupakan satuan pelaksana utama kewilayahan yang berada di bawah polri. Polda membawahi kepolisian negara republik indonesia resor (polres), visi dari polda lampung adalah terwujudnya polda lampung yang profesional, unggul, dapat dipercaya dalam memelihara keamanan dan ketertiban masyarakat yang berlandaskan gotong royong guna mendukung percepatan pembangunan provinsi lampung yang maju dan sejahterah. Banyak nya laporan pencurian dikalangan masyarakat lampung dari kurun waktu ke waktu, serta minimnya informasi data kendaraan hilang yang dimiliki serta kesulitan nya berbagi informasi kendaraan hilang atar wilayah menjadikan polda lampung untuk dapat lebih meningkatkan kualitas sistem kerja didalamnya, pembangunan sistem dalam kasus ini akan diselesaikan oleh genetik Fuzzy sistem, terutama pengembangan struktur genetik Fuzzy metodologi, yang telah memungkinkan logika fuzzy berbasis kecerdasan buatan untuk mengembangkan aplikasi yang dapat diterapkan untuk masalah yang sangat kompleks. Kemampuan perolehan informasi Fasilkom memiliki kinerja ekstrem dan efisiensi komputasi juga akan kuat untuk ketidakpastian dan keacakan. Dengan adanya DPB Ranmor menjadi salah satu aplikasi solusi ideal dalam pengembangan sistem berbasis IT dengan penggunaan Genetic Fuzzy.
\end{abstract}

Kata kunci: Sistem Fuzzy Genetik; Kecerdasan Buatan; Pencarian Informasi; Aplikasi 


\section{PENDAHULUAN}

Pencurian kendaraan bermotor di Provinsi Lampung telah sangat mengganggu, di beberapa daerah telah sangat diresahkan karena tindakan kekerasan yang dapat membahayakan kehidupan atau kematian. Polda lampung merupakan satuan pelaksana utama kewilayahan yang berada di bawah polri. Polda membawahi kepolisian negara republik indonesia resor (polres), visi dari polda lampung adalah terwujudnya polda lampung yang profesional, unggul, dapat dipercaya dalam memelihara keamanan dan ketertiban masyarakat yang berlandaskan gotong royong guna mendukung percepatan pembangunan provinsi lampung yang maju dan sejahterah

Banyak nya laporan pencurian dikalangan masyarakat lampung dari kurun waktu ke waktu, serta minimnya informasi data kendaraan hilang yang dimiliki serta kesulitan nya berbagi informasi kendaraan hilang atar wilayah menjadikan polda lampung untuk dapat lebih meningkatkan kualitas sistem kerja didalamnya. Hasil laporan dari pencurian kendaraan dapat dipindah kemana saja di Provinsi Lampung, terutama di Kabupaten terdekat. Polisi juga mengadakan penangkapan kendaraan yang mana sering ditemukan kendaraan yang tidak memiliki surat lengkap tetapi beberapa kasus yang cukup sulit untuk menemukan pemilik kendaraan. Sehingga dibutuhkan sistem pendukung pelayanan agar dapat meningkatkan kinerja kepada masyarakat. Berdasarkan laporan kehilangan di kepolisian terdekat dan berdasarkan data korban tersebut. Sehingga dengan demikian Penulis dapat mengembangkan aplikasi yang dapat membantu menemukan kendaraan hilang berdasar data yang dilaporkan yang kemungkinan barang curian tersebut ditemukan lokasi yang berbeda

\section{KERANGKA TEORI}

\section{a. Aplikasi}

Aplikasi adalah penggunaan atau penerapan suatu konsep yang menjadi pokok pembahasan. Aplikasi dapat diartikan juga sebagai program komputer yang dibuat untuk menolong manusia dalam melaksanakan tugas tertentu menurut (Jogiyanto, 2005).

\section{b. Basis Data ( Database)}

Database adalah " kumpulan file-file yang saling berelasi, dan relasi itu biasanya ditunjukkan dengan kunci dari tiap file yang ada (Harianto Kristanto, 1993). Dalam suatu file terdapat record-record yang sejenis dan merupakan satu kumpulan entity yang seragam. Satu record terdiri dari field-field yang saling berubungan untuk menunjukkan bahwa field tersebut dalam satu pengertian yang lengkap dan direkam dalam satu record. Dalam model database yang penulis gunakan untuk meracang hubungan antara file yaitu model data relational (entity relational). Pada model ini hubungan antara file direlasikan dengan kunci utama dari masing-masing file. Relasi antara dua file atau dua table dapat dikategorikan menjadi tiga macam, demikian pula untuk membantu gambaran relasi secara lengkap terdapat juga tiga macam relasi dalam hubungan atribut dalam satu file:

\section{c. Lingkup Perancangan}

Perancangan perangkat lunak meliputi :

a. Perancangan data fokusnya pada pendefinisian struktur data

b. Perancangan Arsitektur mendefinisikan hubungan antara elemen utama dari struktur program

c. Perancangan antar muka mendefinisikan rancangan tampilan dan media interaksi antara

d. perangkat lunak dengan entitas luar 
e. Perancangan prosedural merupakan transformasi elemen dari struktur program ke dalam deskripsi prosedural dari perangkat lunak

\section{d. Impelementasi}

Implementasi adalah proses untuk memastikan terlaksananya suatu kebijakan dan tercapainya kebijakan tersebut. Impelementasi juga dimaksudkan menyediakan sarana untuk membuat sesuatu dan memberikan hasil yang bersifat praktis terhadap sesama. Van Horn Dan Van Meter mengartikan Implementasi kebijakan sebagai: "tindakan-tindakan oleh individu publik dan swasta (atau kelompok) yang diarahkan pada prestasi tujuan yang ditetapkan dalam keputusan kebijakan sebelumnya".(Van Horn Dan Van Meter dalam Subarsono,2006).

\section{e. Alat Pengembangan Sistem}

Pada sub bab ini akan diuraikan mengenai alat-alat yang digunakan dalam pengembangan sistem antara lain :

\section{Bagan Alir Dokumen}

Bagan alir dokumen merupakan bagan alir yang menunjukkan arus dari laporan dan formulir termasuk tembusan-tembusan (Jogiyanto, 2005). Simbol yang digunakan adalah sebagai berikut :

Tabel 1 Simbol untuk Bagan alir dokumen

\begin{tabular}{|c|c|}
\hline Simbol & Keterangan \\
\hline Simbol dokumen & $\begin{array}{l}\text { Menandakan dokumen, bisa dalam bentuk surat, formulir, } \\
\text { buku/bendel/berkas atau cetakan }\end{array}$ \\
\hline Simbol kegiatan manual & $\begin{array}{l}\text { Menunjukan pekerjaan yang dilakukan tidak dengan program } \\
\text { komputer. }\end{array}$ \\
\hline Simbol simpanan / arsip & Menunjukkan dokumen yang diarsipkan (arsip manual) \\
\hline Simbol proses & $\begin{array}{l}\text { Menunjukan kegiatan proses yang dilakukan dengan } \\
\text { program komputer }\end{array}$ \\
\hline Simbol Hard Disk & Menunjukan input / output menggunakan hard disk \\
\hline Simbol terminasi & Menunjukan awal atau akhir dari suatu proses. \\
\hline
\end{tabular}




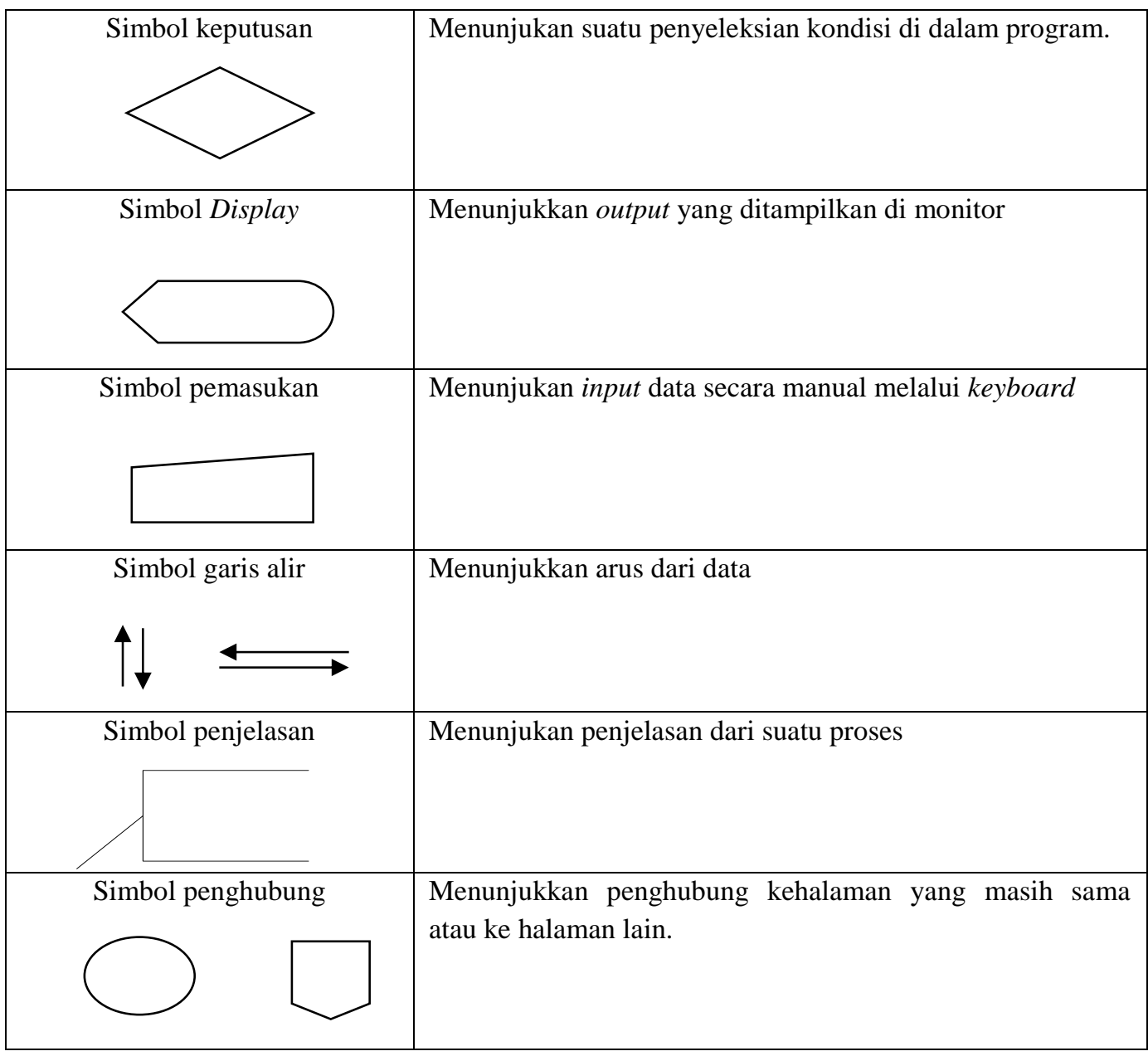

Bagan Alir Program

Bagan alir program merupakan bagan yang menjelaskan secara rinci langkah-langkah dari proses program. Bagan Alir Program adalah gambaran dua dimensi sebagai gambaran lain dari algoritma dengan menggunakan alat/simbol-simbol yang baku. Seadangkan algoritma adalah perhitungan matematika yang menggunakan tanda-tanda $:+,-, * . /$.

Adapun simbol-simbol yang digunakan dalam Diagram Alir Program :

Tabel 2 Simbol untuk Bagan Alir Program

\begin{tabular}{|c|c|}
\hline SIMBOL & KETERANGAN \\
\hline Input/output & Digunakan untuk mewakili data input/output \\
\hline & \\
\hline Proses & Digunakan untuk mewakili suatu proses \\
\hline & \\
\hline
\end{tabular}




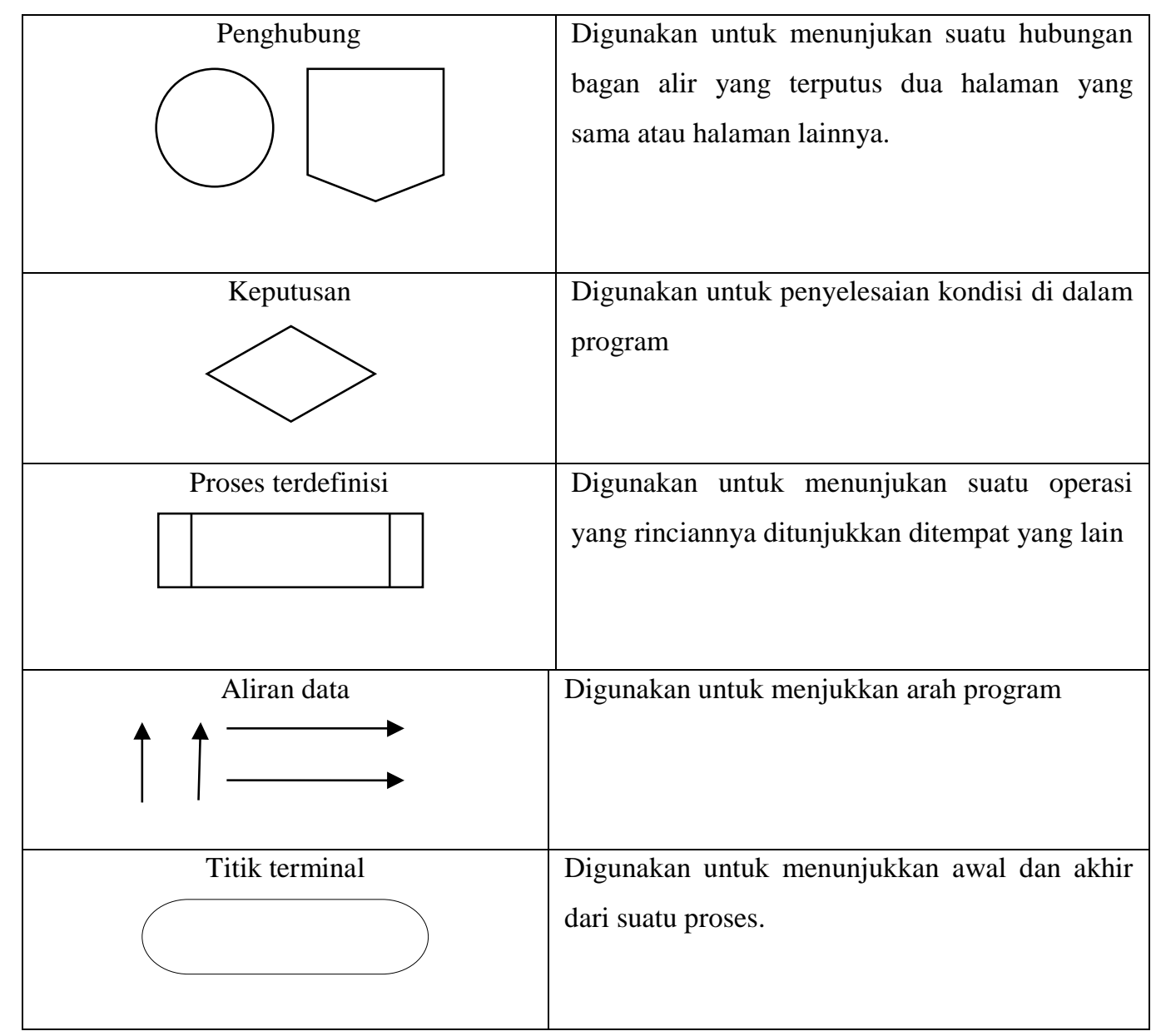

Normalisasi

Dalam merancang basis data, dapat dilakukan dengan menerapkan normalisasi terhadap struktur tabel yang telah diketahui. Adapun tahap-tahap dalam normalisasi adalah sebagai berikut:

1. Relasi bentuk tidak normal (Un Normalized Form/UNF)

Relasi UNF mempunyai kriteria sebagai berikut:

a. Jika relasi mempunyai bentuk non flat file (terjadi akibat data disimpan sesuai dengan kedatangannya, sehingga tidak memiliki struktur yang sama terjadi duplikasi atau tidak lengkap).

b. Jika relasi memuat set atribut berulang (non single value).

c. Jika relasi memuat atribut non atomic value.

2. Relasi bentuk normal pertama (First Norm Form/1NF)

Relasi disebut sebagai 1NF jika memenuhi kriteria sebagai berikut:

a. Jika seluruh atribut dalam relasi bernilai atomik (atomic value).

b. Jika seluruh atribut dalam relasi bernilai tunggal (single value).

c. Jika relasi tidak memuat set atribut berulang.

d. Jika semua record mempunyai sejumlah atribut yang sama.

3. Bentuk normal kedua (Second Norm Form/2NF)

Relasi disebut sebagai $2 \mathrm{NF}$ jika memenuhi kriteria sebagai berikut:

a. Jika memenuhi kriteria 1NF.

b. Jika semua atribut non kunci FD pada PK 
4. Bentuk normal ketiga (Third Norm Form/3NF)

Suatu relasi disebut $3 \mathrm{NF}$ jika memenuhi kriteria sebagai berikut:

a. Jika memenuhi kriteria $2 \mathrm{NF}$.

b. Jika setiap atribut non kunci tidak TDF (non transitive dependency) terhadap PK.

5. Bentuk normal keempat (Fort Norm Form/4NF)

Relasi disebut 4NF jika memenuhi kriteria sebagai berikut:

a. Jika memenuhi kriteria $3 \mathrm{NF}$.

b. Jika atribut didalamnya tidak mengalami ketergantungan pada banyak nilai atau dengan kata lain bahwa semua atribut yang mengalami ketergantungan pada banyak nilai adalah bergantung secara fungsional (Jogianto, 2005)

\section{METODOLOGI}

Waterfall Model (Sommerville:2007) memiliki tahapan sebagai berikut :

a. Requirements analysis and definition

Requirements analysis and definition dilakukan terhadap data yang ada serta mengumpulkan kebutuhankebutuhan perangkat lunak yang akan dibangun. Merupakan tahap dimana inisialisasi pendefinisian masalah untuk penyelesaian teknis pengembangan perangkat lunak mulai dilakukan.Terminasi tahap analisis, pada saat telah didapatnya definisi permasalahan yang disetujui oleh pengguna dan pengembang.

b. System and software design

Pada tahap desain dilakukan pengubahan kebutuhan-kebutuhan menjadi bentuk karakteristik yang dimengerti perangkat lunak sebulum dimulai penulisan program. Adapun proses yang dilakukanpada tahap ini adalah:

$\checkmark \quad$ Mendekomposisi modul sistem yang akan dikembangkan

$\checkmark \quad$ Penetapan rancangan masukan dan keluaran yang diperlukan

$\checkmark \quad$ Penetapan struktur data yang dipilih

$\checkmark \quad$ Penetapan prosedur kerja internal

$\checkmark \quad$ Penetapan formula pengolahan data

c. Implementasi and unit testing

Pada tahap ini, perancangan perangkat lunak direalisasikan sebagai serangkaian program atau unit program. Pengujian unit melibatkan verifikasi bahwa setiap unit telah memenuhi spesifikasinya.

\section{d. Integration and system testing}

Unit program atau program individual diintegrasikan dan uji sebagai sistem yang lengkap untuk menjamin bahwa persyaratan sistem telah dipenuhi.

\section{e. Operation and maintenance normally}

Ini merupakan fase siklus yang paling lama. Pemeliharaan mencakup koreksi dari berbagai error yang tidak ditemukan tahap-tahap sebelumnya. 


\section{HASIL DAN PEMBAHASAN}

Metodologi GFT

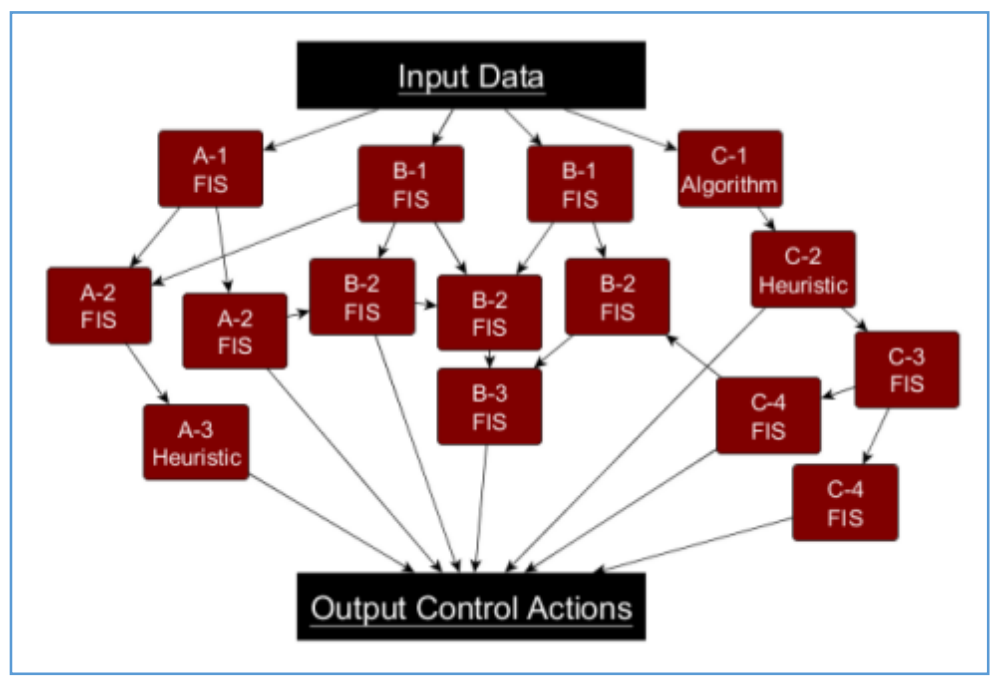

Gambar 1 Contoh Tata Letak Pohon Fuzzy

Metodologi GFT menggunakan koleksi Fuzzy kesimpulan sistem (FIS) dengan berbagai tingkat konektivitas. Tidak seperti sistem kabur genetik standar, berikut algoritma genetik, atau sistem belajar lainnya, digunakan untuk secara bersamaan melatih setiap sistem di Fuzzy pohon .

FIS masing-masing memiliki fungsi keanggotaan yang menggolongkan input dan output untuk klasifikasi linguistik, seperti "remote" dan "sangat mengancam", dan jika-maka aturan untuk setiap masukan kombinasi, seperti " jika Cari bingkai tidak ada atau tidak ada mesin maka data akan ditemukan dengan sangat tinggi akurasi ".

Dengan meruntuhkan banyak sub-keputusan, ruang solusi berkurang secara signifikan. Biaya pendekatan ini adalah risiko tidak mengakomodasi semua sumber kopling. Melalui desain yang optimal ini bisa diminimalisir jika tidak semuanya berkurang. Tidak seperti di Fuzzy Decision Trees atau Fuzzy Networks, fuzzy bukan GFT bukanlah komponen individual FIS, melainkan FIS yang unik tersendiri.

Konsep pencarian informasi (IR) telah dikembangkan sehubungan dengan sistem database selama bertahuntahun. Pencarian informasi adalah asosiasi dan pengambilan informasi dari sejumlah besar berbasis teks pencarian informasi dan sistem database, setiap menangani berbagai jenis data; Beberapa masalah sistem database biasanya tidak hadir dalam sistem pencarian informasi, seperti kontrol concurrency, pemulihan, pengelolaan transaksi dan update. Beberapa masalah umum pencarian informasi biasanya tidak ditemui dalam sistem database konvensional, tidak terstruktur dokumen, perkiraan Cari berdasarkan kata kunci dan konsep relevansi. Karena jumlah besar informasi tekstual, Cari informasi telah menemukan banyak aplikasi. Ada banyak sistem informasi, seperti on-line Perpustakaan

Katalog sistem, sistem manajemen dokumen baris, dan baru saja dikembangkan Web mesin pencarian Metode ekstraksi informasi mengidentifikasi kata kunci dan hubungan dalam teks. Hal ini dilakukan dengan mencari urutan yang telah ditentukan sebelumnya dalam teks, sebuah proses yang disebut pencocokan pola.

Perangkat lunak akan meningkatkan hubungan antara semua diidentifikasi tempat, orang dan waktu untuk memberikan pengguna informasi tersebut. Teknologi ini sangat berguna ketika berhadapan dengan volume besar teks. Penggalian data tradisional mengasumsikan bahwa informasi "ditambang" sudah dalam bentuk database relasional. informasi elektronik hanya tersedia dalam bentuk dokumen bahasa alami gratis dan bukan database terstruktur [1]. Proses ini diilustrasikan pada Gambar 2. 


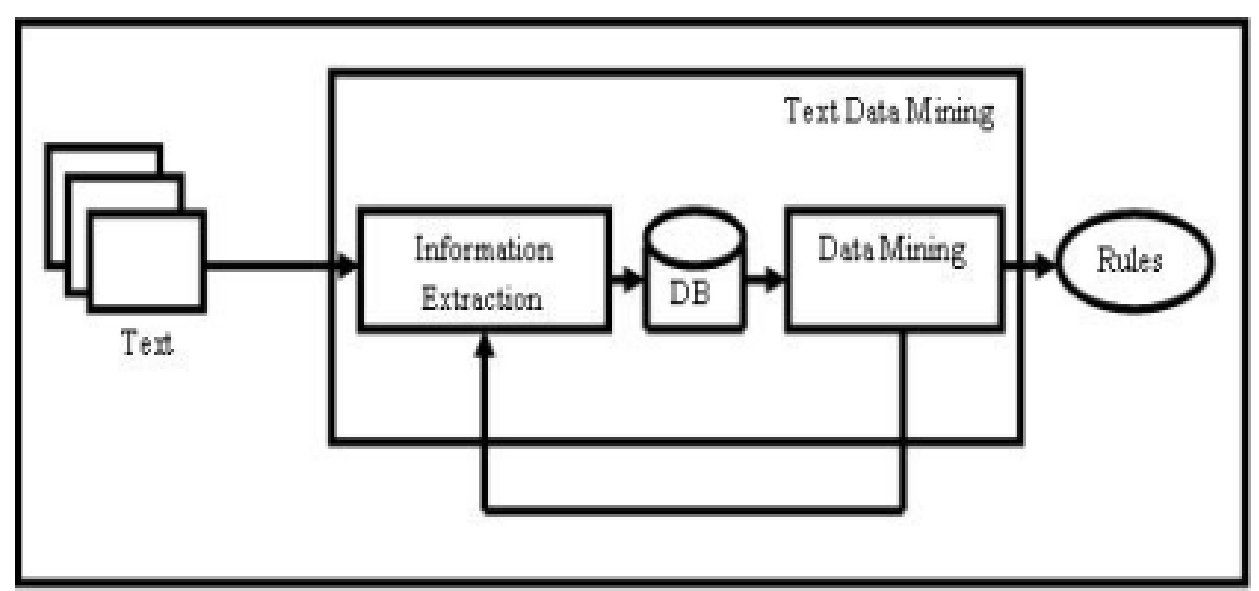

Gambar 2: Proses Ekstraksi Teks

Berikut adalah implementasi yang dijelaskan dalam bentuk ayah, yang akan dijadikan dasar pembuatan aplikasi DPB Ranmor 2.0 Proses ini diilustrasikan pada Gambar 3

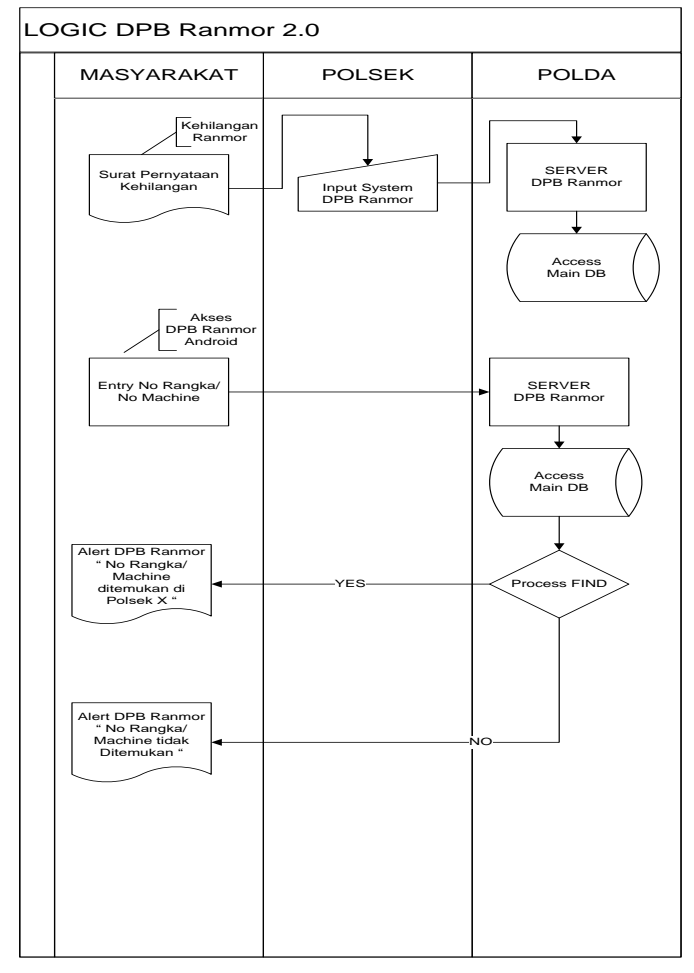

Gambar 3 DAD Program 
Pada langkah ini hasil yang didapat adalah:

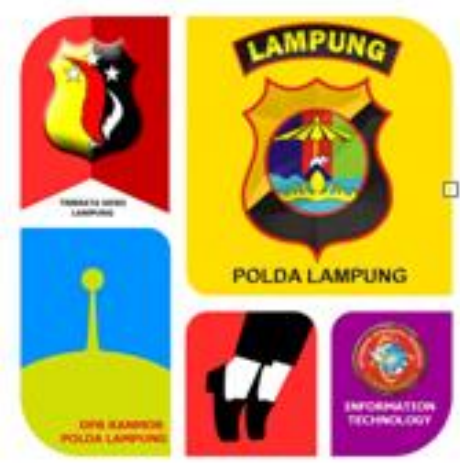

Gambar 4 Logo DPB Ranmor 2.0

Berfungsi sebagai tampilan yang akan digunakan oleh pengguna untuk mendownload diplaystore, Proses ini diilustrasikan pada Gambar 4

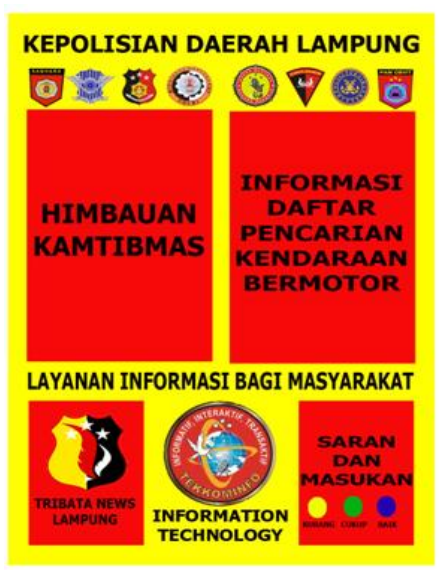

Gambar 5 Menu Utama

Berfungsi sebagai tampilan awal yang akan mengarahkan pengguna untuk mengakses pilihan, Proses ini diilustrasikan pada Gambar 5

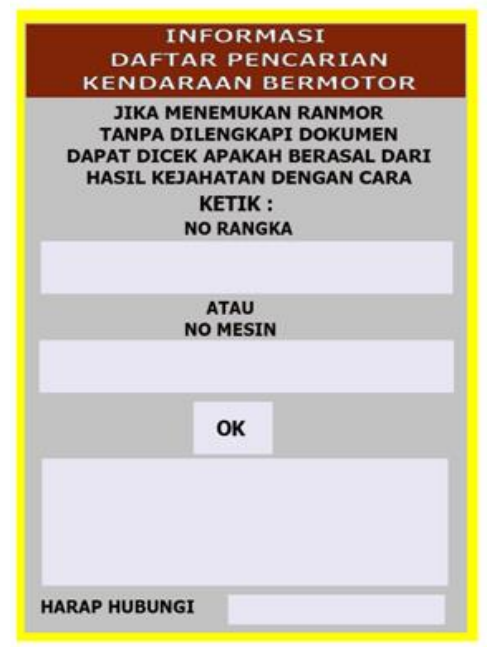

Gambar 6 Menu Pencarian 


\section{KESIMPULAN}

DPB Ranmor 2.0 menyediakan solusi untuk ketersediaan kebutuhan data berbasis teks besar untuk dikaji guna mendapatkan informasi berharga. Text mining Teknik yang digunakan untuk menganalisis informasi yang menarik dan relevan secara efektif dan efisien dari sejumlah besar data tidak terstruktur Makalah ini menyajikan ikhtisar singkat teknik penambangan teks yang membantu memperbaiki proses penambangan teks menggunakan Genetic Fuzzy yang diterapkan dalam Information Retrieval. Pola dan urutan spesifik diterapkan secara berurutan untuk mengekstrak informasi yang berguna dengan menghilangkan rincian yang tidak relevan untuk analisis prediktif. Seleksi dan penggunaan yang tepat teknik dan alat sesuai domain membantu membuat text mining Prosesnya mudah dan efisien. Integrasi pengetahuan domain, perumusan konsep yang beragam, penyempurnaan teks multibahasa, dan keterampilan pengolahan bahasa alami adalah isu dan tantangan utama yang muncul selama proses penambangan teks.

\section{DAFTAR PUSTAKA}

Ernest N, Cohen K; Garcia E; Schumacher C; Casbeer D.2015. Multi Agents Cooperative Decision Making Using Genetic cascading Fuzzy System. AIAA SciTech Conference.

Ernest N, Cohen K, Kivelevitch E, Schumacher C, Casbeer D. 2015. Genetic Fuzzy Trees and their Application Towards Autonomous

Funchun Peng, Nawaaz Ahmed; Xin Li; Yumao Lu.1998. Context Sensitive Stemming For Web Search.

Procedings of the $30^{\text {th }}$ Annual International.

Mujilahwati S.2016. Pre Processing Text Mining Pada Twitter. Yogyakarta. Seminar Nasional Teknologi Informasi dan Komunikasi.

Talib R; Muhammad KH; Shaeela Ayesha; Fakeeha Fatima. 2016. Text Mining : Techniques, Application and Issue. International Journal of Advanced Computer Science and Application. IJACSA

Vijayarani Dr.S; Ilamathi Ms.J ; Nithya Ms.2016. Processing Techniques for text Mining. International Journal of Computer Science \& Communication Networks. INDIA 